\title{
Sivil Toplum Örgütleri ve Dijital Dönüşümler: Kuzey Kıbrıs Kadın Sivil Toplum Kuruluşları Üzerine Bir İnceleme*
}

\author{
Dilan Çiftçi (Dr. Öğr. Üyesi) \\ Yakın Doğu Üniversitesi İletişim Fakültesi \\ dilan.ciftci@neu.edu.tr \\ ORCID: 0000-0003-3806-3915
}

Başvuru Tarihi: 16.06.2019

Yayına Kabul Tarihi: 30.09.2019

Yayınlanma Tarihi: 24.01.2020

DOI: http://10.17680/erciyesiletisim.578496

\section{Öz}

Günümüzde, neredeyse her alanda hizmet veren kurum ve kuruluşların iletişim pratiklerinde sosyal medyanın önemli bir araç haline geldiği yadsınamaz bir gerçektir. Sivil toplum kuruluşlarının iletişim stratejileri ve iletişim süreçlerine bakıldığında geleneksel medya daha baskın olarak görülmesine rağmen, son dönemlerde sosyal medyanın sivil toplum kuruluşları için vurgusu belirgin olarak ortaya konmuştur. Sosyal medyanın içerik üretimi, tüketimi ve yeniden üretimi süreçlerinde çok kanallı yapısının faydalarının yanında, sivil toplum kuruluşlarının görünürlügü açısından da olumlu sonuçlar doğurduğu örneklerle ortaya konulmuştur. Tüm bu gelişmeler, sivil toplum kuruluşlarının paydaşları ile iletişimindeki önemli bir çalışma kolu olan sosyal medya ile dönüşen sivil toplum kuruluşları alt başlığında yeni tartışmalara yer açmıştır.

$\mathrm{Bu}$ bilgiler ışığında, çalışmada sivil toplum kuruluşlarının sosyal medya kullanım pratikleri iki aşamada incelenmiştir. Bu bağlamda çalışmanın ilk aşamasında, Kuzey Kıbrıs Türk Cumhuriyeti'ndeki resmi kayıtlı kadın sivil toplum kuruluşlarının sosyal medya mecralarındaki (Facebook, Twitter ve Instagram) görünürlükleri ortaya konmuştur. Çalışmanın ikinci aşamasında ise Kuzey Kıbrıs'taki kadın aktivist hareketlerin ve sivil toplum kuruluşlarının önde gelen aktif bir örneği olan Mesarya Kadınları İnisiyatifi'nin resmi Facebook hesabına yönelik 1 Ocak 2019-31 Mart 2019 tarihleri arasında 3 (üç) aylık içerik analizi uygulanmıştır. Bu yolla, söz konusu paylaşımları üzerinden sosyal medya kullanım pratiklerinin betimlenmesi amaçlanmaktadır. Kuzey Kıbrıs özelinde, sivil toplum kuruluşlarına yönelik yapılan çalışmaların sınırlı sayıda olması ve kadın sivil toplum kuruluşları ile yapılan çalışmaların eksikliği bu çalışmanın özgünlügünnü ve literatüre katkısını ortaya koymaktadır.

Anahtar Kelimeler: Sivil Toplum Kuruluşları; Dijital Dönüşümler; Sosyal Medya; Kadın Kuruluşları; Mesarya Kadınları İnisiyatifi; Kuzey Kıbrıs.

\footnotetext{
* Bu çalışma 2-3 Mayıs 2019. tarihinde İstanbul'da düzenlenen 6. Uluslararası Illetişim Günleri Sempozyumu’nda "Sivil Toplum Örgütleri ve Dijital Dönüşümler: Kuzey Kıbrıs Kadın Sivil Toplum Kuruluşları Üzerine Bir İnceleme” başlı̆ııla sunulan bildirinin genişletilmiş halidir.
} 


\title{
Nongovermental Organizations and Digital Transformations: An Investigation on Northern Cypriot Women's Civil Society Organizations
}

\author{
Dilan Çiftçi (Asst. Prof. Dr.) \\ Near East University Faculty of Communication \\ dilan.ciftci@neu.edu.tr \\ ORCID: 0000-0003-3806-3915
}

Date Received: 16.06.2019

Date Accepted: 30.09 .2019

Date Published: 24.01.2020

DOI: http://10.17680/erciyesiletisim.578496

\begin{abstract}
It is an undeniable fact that social media has become an important tool in the communication practices of the institutions and organizations serving in almost every field today. Although traditional media is more dominant in the context of communication strategies and communication processes of civil society organizations, the emphasis of social media on civil society organizations has been highlighted recently. In addition to the benefits of multichannel structure in the content production, consumption and reproduction processes of social media, it has been shown with examples that have positive results in terms of the visibility of civil society organizations. All these developments have opened up new debates in the sub-topic of non-governmental organizations transformed by social media, which is an important part of the communication of civil society organizations with stakeholders.
\end{abstract}

In the light of this information, social media usage practices of non-governmental organizations were examined in two stages. In this context, in the first phase of the study, the visibility of officially registered female non-governmental organizations in the Turkish Republic of Northern Cyprus on social media channels (Facebook, Twitter and Instagram) has been revealed. In the second phase of the study, 3 (three) months content analysis was conducted between January 1st, 2019 and March 31st , 2019 for the official Facebook account of the Mesarya Women Initiative, a leading active example of womenactive movements and civil society organizations in Northern Cyprus. In this way, it is aimed to describe social media practices through these shares. The limited number of studies conducted for non-governmental organizations in terms of Northern Cyprus and the lack of studies with women's civil society organizations reveal the specificity of this study and its contribution to the literature.

Keywords: NGOs; Digital Transformations; Social Media; Women's Organizations; Initiative of Mesarya Women; North Cyprus. 


\section{Giriş}

Teknolojik gelişmeler ve modernlik tartışmaları uzun süredir devam ederken, bilgi ve iletişim teknolojilerinin baş döndürücü hızda gelişmesi ve yaygınlaşması da teknoloji ve modernliğe dayanan küresel kültürün ortaya çıkmasına olanak sağlamaktadır. Bilindiği üzere demiryolları, buharlı gemiler, otomobil ve uçağın icadıyla başlayan ulaşım ve iletişim teknolojileri, telekomünikasyonda maliyetleri düşüren mikroçipler, uydu antenleri, fiber-optik teknoloji ve internet ile devam etmiştir. İnternetin yaygın kullanımı ile birlikte bilgiye erişimin kolaylaşması yalnızca kişilerarası iletişimi etkilememiş, aynı zamanda kitle iletişiminin de hem hızını yükseltmiş hem de erişilebilirliğini artırmıştır. Tüm bu gelişmeler, gündelik hayat pratiklerini de doğrudan etkilemektedir. Ayrıca yeni iletişim teknolojileri ile birlikte bireyler aktif olarak iletişim sürecine katılarak edilgen durumdan etken duruma geçme imkanı yakalamıştır. Kitle iletişim araçlarının internet tabanlı olarak kullanılması mesajların sınırlarının genişletilmesine olanak sağlamıștır.

Teknolojik gelişmeler ve modernlik tartışmaları ışığında küreselleşme olgusu diğer tartışmalar gibi önemini korumuş ve internetin bilgiyi yayma hızının beraberinde getirdiği asıl dönüşüm olan web 2.0 teknolojilerinin siber kamusal alanlar oluşturması durumu önem kazanmıştır. İyimser bakış açısıyla yaklaşıldığında, yeni medya teknolojileri, siber bir kamusal alan haline bürünürken aslında sivil iradenin gücünü göreceli olarak artırmış ve daha katılımcı demokratik bir süreci de gündeme getirmiştir. Bir başka deyişle, yeni iletişim ortamları muhalif kesimlere seslerini duyurmada başvurabilecekleri ortamları sunması itibariyle, internet aracılığıyla örgütlenme tartışmalarına da ışık tutmuştur. Yeni dünya düzenine bakıldığında ise Kuzey Kıbrıs Türk Cumhuriyeti (KKTC) ve Türkiye'de dahil olmak üzere türlü türlü örneklerde sosyal ağlar kullanılarak siber ortamlarda aktifleșen küresel etkileşimlere rastlamak mümkündür (Ciftci, 2018; Themistocleous, 2017; Kaya \& Sagsan, 2015; Komodromos, 2014).

Facebook, Twitter, Instagram vb. gibi sosyal paylaşım ağlarında, insanların yeni bir kamusallık etrafında toplanması ve muhalif seslere yer vererek milyonlara ulaşabilmesi, dönüşen toplumsal hareketlerin ve aktivizmin de örneğini oluşturmaktadır. $\mathrm{Bu}$ çalışmada yeni medya ortamı ve bu yeni medya ortamında var olabilmeleri açısından Kuzey Kıbrıs Türk Cumhuriyeti'ndeki kadın sivil toplum kuruluşları irdelenecek ve alternatif toplumsal aktivist hareketi olarak Mesarya Kadınları Inisiyatifi'nin sosyal medya paylaşımlarının betimsel analizi yapılacaktır. Çalışma kapsamında ele alınan kadın sivil toplum kuruluşları KKTC İç İşleri Bakanlığı tarafından resmi olarak kaydedilmiş kadın kuruluşlarından oluşurken, aktivist hareket olarak ele alınan Mesarya Kadınları Inisiyatifi ise kadın sorunlarına karşı ortaya koydukları tepkiyi yeni medya ortamlarından yararlanarak geliștirmesindeki gösterdikleri performans ile öne çıkmaktadır. Yeni medyanın ve yeni temsiliyetleri oluşturması konusu önemli bir tartışma alanı açmakla birlikte, yeni medya ile muhalif politik seslere yer açarak sivil toplum kuruluşlarının etkinliklerini ve örgütleme pratiklerinin kapsamını ve kapasitesini artırması ayrı bir tartışma alanını oluşturmaktadır. Bu nedenle, bu çalışmada yeni medya ve ağ üzerinden paydaş iletişiminin kapasitesini artıran sivil toplum kuruluşlarının ağlar üzerinden kamuoyuna ulaşıp ulaşmadığı sorgulanacak ve bu bağlamda KKTC kadın sivil toplum örgütlerinin dijital dönüşümün çerçevesinin ortaya konulmasına odaklanılacaktır.

$\mathrm{Bu}$ çalışmada, bireylere ulaşmada ve yetkilileri harekete geçirmede organizasyonel kamuyu oluşturan sivil toplum kuruluşlarının geleneksel medyada seslerini duyurmada ve yer bulmada yaşadıkları sınırlılıkların ortadan kalkarak onlara alanlar sağlayan yeni medya ve ağların enformasyonun içeriği üzerindeki kontrolü ve üretkenliği tartışılacaktır. 
Bu bağlamda alternatif medya olarak ifade edilecek olan yeni ağlar, toplumsal özgürleşim beklentileri ışığında Mesarya Kadınları Ínisiyatifi örneklemi çerçevesinde kullanım pratikleri ile alternatif düşüncelere yer verme olanakları ile tartışılacaktır.

\section{Kavramsal Çerçeve}

\subsection{Küreselleşme, Yeni Medya Ortamı ve Toplumsal Değişim}

Küreselleşme, son yıllarda hemen hemen her alanda sıkça tartışılan ve her tartışma ortamında kendisine farklı anlam, değerler ve eleștiriler yüklenen bir kavram olarak sosyal bilimlerde yerini fazlasıyla sağlamlaștırmıştır. Tutar'a (2000, s.18)'e göre, dünyanın tek bir mekan olarak algılanabilecek ölçüde sıkışıp küçülmesi anlamına gelen bir süreci... ifade eden bu kavram, ekonomik, siyasal, sosyal ve kültürel değerlerin çerçevesinde daha küresel ölçekte değerlendirilmesidir. Küreselleşme kelimesinin medya ve iletişim çalışmaları disiplininde nerdeyse temel kaynak olarak kabul gören McLuhan ise 1962 yılında küreselleşme ve yeni medya teknolojilerinin sınırları ortadan kaldıran etkisi ile küresel köy (global village) terimini ilk defa kullanmıştır. Bu yaklaşımdan yola çıkarak, şu şekilde bir çıkarım yapmak doğru olacaktır: kitle iletişim araçlarının yaygınlaşması ile birlikte mekanlararasılık yani fiziki mekanın yeni boyutu hız kazanmış ve birey coğrafi sınırların ötesine geçebilir ve sınırlar aşırı bilgiye kolaylıkla ulaşabilir hale gelmiștir (Chow, 2012).

Bütün bu gelişmeler ışığında ise yeni medya teknolojileri ile edilgen durumda bulunan kitlelerin seslerini duyurmaları daha kolay hale gelmiş, özgür ve geniş alanlar sunan internet kamusal alanın boyutlarını genişletmiş ve yönünü çoğaltmıştır. Geleneksel medyadaki içeriğin belirlenmesindeki merkeziyetçi yaklaşımın yerine geçen çeşitlenme, parçalanma ve çok merkezli kontrol hegemonyaları zayıflatarak yeni seslerin duyulmasına olanak sağlamaktadır (Timisi, 2003, s. 83-84). Bir başka deyişle yeni medya, birbirinden farklı ve etkileşimli ortamları bir araya getirmesiyle ortaya çıkan çoklu ortamlar (Dilmen, 2007, s. 115) her açıdan insanlığa ve sivil toplum kuruluşlarına yeni medya teknolojileri ile birlikte çok önemli kolaylıklar sağlamıştır (Altunay, 2012, s. 41). Bu durum pek çok örnekte karşımıza gelişim ve değişimle birlikte çıkmaktadır. Bununla birlikte gelişim ve değişimin başarıya götüren en güzel örneği Somali Stratejik İletişim Grubu olarak gösterilebilir (Ciftci, 2019). Stratejik İletişim ve Halkla İlişkiler Grubu (SCPAG), UNSOM'un görevine uygun olarak medya ilişkileri, araștırma ve tanıtımla birlikte iletişim faaliyetleri ve ürünleri için stratejik destek sağlamaktadır. Soydan (2012) bütün bu gelişmelerin, sivil toplum hareketlerini geleneksel medyanın tek yönlü iletişiminden koparak kendi sosyal medyaları aracılığı ile çift yönlü iletişim süreçlerine dahil olarak kendi ağ topluluklarını oluşturur ve yönetir hale geldiklerini savunmaktadır. Öyle ki bu durum enformasyonu yönlendirerek kitleleri mobilize etmede biriken kitlesel enerjileri meydanlara taşımış ve toplumsal hareket noktalarını oluşturmuştur (Soydan, 2012, s. 52). Diğer taraftan bu durumda sanal topluluklar da kendini göstermeye başlamıştır (Ciftci, Erdem ve Ciftci, 2017). Buradan yola çıkarak, çalışmanın analizi yapılırken genel hatları belirlemede kullanılacak olan yeni medyanın temel özelliklerine değinmek yerinde olacaktır. Bu bağlamda, yeni medya için Richard Rogers'ın (2005) ortaya koyduğu üç ana özellik bulunmaktadır. Bunlar (Geray, 2003, s. 18):

Etkileşim \{interaction\}: Yeni medya ile ortaya çıkan ve kuşkusuz en önemli özellik olan etkileşim ile alıcı ve verici arasında gerçekleşen iletişim sürecinde iki tarafta aktif rol almaktadır. Bu noktada etkileşim ile edilgen bir sürece dönüșen iletişim sürecinin en önemli aracı olarak internetin altını çizmek yerinde olacaktır. 
Kitlesizleștirme \{demassification\}: Yeni medya kitleleri harekete geçirirken aynı zamanda her bir bireye özel mesaj yollayabilme imkanı sunması açısından kitlesizleștirici olabilme özelliğini de içerisinde barındırmaktadır.

Eşzamansızlık \{asekron\}: Sınırların ve aynı anda, aynı yerde bulunma gerekliliğinin ortadan kalkmasını ifade etmektedir.

Bütün bu bilgiler ışığında, yeni medya ve demokrasi kavramlarını birlikte düşündüğümüz zaman, yeni medyanın etkileşim özelliğinden yola çıkarak katılımcı demokrasiyi gerçekleştirmede önemli bir araç olduğunu söylemek yerinde olacaktır (Karapınar, 2006, s. 97). Buna ek olarak, Friedman ve Underwood bu durumu tanımlarken bireylere farklı anlamlar yükleyerek Friedman (2009) yeni medya ortamlarındaki bireylere süper güçlendirilmiş birey derken, Underwood ise yeni medya ile güç dengesinin tek'ten çok'a durumundan sıyrılarak çok'tan çok'a geçtiğinin altını çizmektedir (Underwood, 2002, s. 136).

Diğer bir açıdan yeni medya ile ortaya çıkan ağ toplumu kavramı ise yeni medyanın etkileşim özelliğinden beslenerek iki yönlü iletişimi desteklemektedir. $\mathrm{Bu}$ iletişim sürecinde sosyal ağlar ile oluşturulan kimlikler ve inşa edilen durumlar ile kitleleri mobilize etmek daha etkili hale gelmiştir (Kesim, 2008, s. 5-6). Bu yaklaşım, ile egemenlik kavramlarının küreselleşme karşısındaki çözülmesi gibi yeni medya karşısında da zayıflayan ulus devletlerin karşısında güçlenen ve etkisini artıran sivil toplum kuruluşlarından bahsetmek yerinde olacaktır (Al, 2002, s. 282).

\subsection{Dijital Toplum, Dijital Aktivizm}

Toplum ve kamusal alan tartışmalarına değinen her çalışmanın merkezi odağı Habermas'ın 18. yüzyılda kapitalist modernliği ile ortaya attığı kamusal alan ile özel alan tartışmalarına değinmektedir. 0 dönemim şartlarında daha sıklıkla burjuva kamusal alanı ile bireylerin kamusal ilgi alanlarını birbirlerine aktardıkları özellikle salonlar ve okur-yazar kulüplerinde yurttaşlık işlevlerini yerine getirdikleri şeklinde ele alınan burjuva kamusal alanı ise zaman içerisinde eksik yönleri bakımında farklı bakış açılarıyla eleştirilmiştir. Bu eleştirilerin içerisinde feminist yaklaşımların pek çoğu Habermas'ın kamusal alan ve özel alan tartışmalarında kadınlar ve azınlık grupların kamusal alanın dışında tuttuğu gerekçesiyle eleştirmiştir (Best ve Kellner, 1998). Bu bağlamda, yeni medya ile dijitalleşen toplumlarda bu durum dönüşmektedir. İnternet ile ortaya çlkan dijital toplumlarda, yurttaşlar kamusal alanla ilişkilerini istedikleri yönde oluşturabilmekte ve yaratıcı bir süreç olarak özel ilgi alanlarına odaklaşan kamusal alanlarla ilişki kurabilmektedir. Mark Poster'e (2018) göre bu durum ikinci medya çağı meyvesi olarak adlandırılmaktadır. Bu noktada yeni medyanın sosyal bağlamı dönüștürme süreci, çalışmanın ana konusunu oluşturan sivil toplum kuruluşları ve sivil hareketlerden Mesarya Kadınları İnisiyatifi'nin bir parçası olarak kabul edilen aktivist hareketlerdeki değişim ve muhalif bakış açısı, dinamik ve kolektif davranışlarla kadınlara söz hakkı tanıması dikkat çekmektedir.

Bütün bu dijital toplum ve yeni kamusal alan tartışmalarının ışığında, dijitalleşen kültür tartışmaları da yerini bulmuştur. Dijital kültür tartışmaları, araştırmacılar tarafından farklı yönleriyle ortaya konulurken, en temel soru, dijital kültürün içinde neleri barındırdığı ve barındırdığı içerikleri nelere dönüştürdüğüdür. Yeni medya, küreselleșen dünyada kültürleri elektronik ortamlarda depolarken, dağıtımını da kolaylaştırmaktadır. Bu durum Manovich'e göre (2001, s. 19) yeni medya devrimi olarak ifade edilmektedir. Bu durumla birlikte ortaya çıkan farklı kültürlerle benzeşmiş 
toplumsallaşma sürecindeki toplumları ise Castelle ve Himanen (2001) siber toplum diye ifade ederken bu toplumların taşıdıkları kültürü ise Jones (1998) internet kültürü olarak ifade etmektedir. Bu noktada, tartışmaların odağını oluşturan ilk sosyal medya ortamlarından bloglar ve web uygulamaları çoğunlukla muhalif olma özellikleri açısından öne çıkarılmış ve hegemonyayı kıran etkilerinden söz edilmiştir (Lovink, 2011, s. 21). Arap Baharı ile birlikte başlayan yeni toplumsal hareketler, tartışmaları aktivist protestoların dijital organizasyonu konusu ise yeni temsiller yaratma ve muhalif politik sesleri duyurma kapasitesini ortaya koymaları bakımından önemlidir (Morozov, 2007; Morozov, 2009a; Morozov, 2009b; Furuncu, 2014; Morozov, 2017). 'Aktivizm ve Yeni Medya' adlı çalışmasında Morozov aktivistlerin yeni medyadan yararlanma stratejilerini sekiz ana başlık altında toplamıștır. Bunlar:

1. Ulaşılabilirlik ve doğru bilgi

2. Belirli bir soruna karşı kamuoyu ilgisini çekmek

3. Seçmenlere yardımcı olmak için verileri analiz etmek ve bir arada bulma kolaylığı sağlamak

4. Politikacılar ve seçmenlerle doğrudan temas kurmak

5. Yeni üyelere ulaşmak

6. Eylemleri mobilize etmek ve lojistik destek sağlamaya yardımcı olmak

7. Kolektif eylemler için yaratıcı yöntemler bulmak ve yenilikler üretmek

8. Diğer sivil toplum kuruluşları ve aktivistler arasında bilgi değişimi ve bunların basılmasını sağlamak (Morozov, 2007; Morozov, 2009a; Morozov, 2009; Morozov 2017).

\subsection{Alternatif Medyanın Kavramsal Analizi}

Alternatif medya kavramı ilk olarak 1960'larda hippi kültürü ve gazetelerle gündeme gelmeye başlamıştır. İlerleyen zamanlarda ise sendika gazeteleri, edebiyat dergileri marjinal müzikler gibi farklı biçimlerde örnekler çoğalmaya başlamıştır. Bunlara ilaveten, dijital radyo istasyonları, feminist radyo Showları ve çevre aktivistlerinin web siteleri gibi farklı örnekleri vermek yerinde olacaktır. Bu örneklerin ortak özelliği olarak ana akım medyada yer bulamayan konu ve seslerin yer almalarına şans vermesidir (Offe, 1999). Öte yandan, Köse, "geleneksel medya söylemine yönelik tartışmalarda, söylemin dünyayı asla bir 'problem algllama ve çözme yeri' olarak görmemesi" olduğunu söyler (Köse, 2007, s. 11). Diğer bir deyişle alternatif medya problemleri ve problemlerin ortaklığını algılama, problemler üstüne konuşma, deneyimlerini birbirleriyle paylaşma yönünde özdüșünümsel bir platform olarak ifade edilebilir.

Diğer bir taraftan Clemencia Rodriguez, yurttaş medyasının çoğunluğun erişimine açık olması ve gönüllülüğe dayanması özelliklerinden yola çıkarak, alternatif medya olarak algılanmasının sorun yaratmayacağı üzerinde durmaktadır. Çünkü Rodrigez’a göre (2000) yurttaş medyası sadece alternatif değil aynı zamanda aktivisttir. Buna ek olarak Waltz (2005) alternatif medyanın özelliklerini aşağıdaki gibi sıralamaktadır:

- Topluluklara hizmet etmesi: Topluluğun önemini ve gücünü temsil eden alternatif medya, aynı zamanda etkileşime olanak sağlayarak aktif katılımını, tartışmaların aktif olarak ortaya konmasını ve bastırılmış konuların açı̆ga çıkmasını sağlar. Belirli amaçlar ve çıkarlar etrafında ağ toplulukları biçimlenirken, ana akım medyadan farklı olarak alternatif medya, izleyici katılımını sağlayan biçimlerde yeni medya ortamlarının kullanımı ve kamusal tartışmalarda kendini ifade edebilme ortamları yaratmada daha başarılıdır. 
- Ana akım medyaya alternatif olması: Örgütlenme biçimlerinin alternatif yollarını gösterir ve farklılaşan söylemlere platform sağlarken, çeşitlilik ve çoğulculuğu teşvik eder. $\mathrm{Bu}$ anlamda alternatif medya, hegemonya karşısında güç gösterecek hegamonik politikalara, önceliklere ve perspektiflere alternatif bakış açısı sunarak önem arz eder (Bailey, Cammaerts ve Carpentieer, 2008, s. 15).

- Alternatif medyayı sivil topluma bağlamasıdır: Sivil toplumun önemini ortaya koyarak kamusal alanda kendilerini ifade etme firsatları yaratır. Bu özellikten yola çıkan yaklaşıma göre alternatif medya, devlet ve özel ticari medya arasında üçüncü sestir ve demokrasi açısından can alıcı önemdedir (Bailey-Cammaerts- Carpentier, 2008, s. 23). Başka bir deyişle, Waltz’a göre (2005, s. 70) katılımcı demokrasinin beslenmesi için alternatif medya bir ihtiyaçtır.

- Rizom olarak alternatif medya: Farklı düşünceden insanları bir araya getiren bir kavşak olarak demokratikleşmeyi güçlendirir. Ele geçirilememezlik özelliği ile ifade özgürlügünü garanti altına alır (Waltz, 2005, s. 3). Toplumsal örgütlerin ve hareketlerin dönüm noktası olarak alternatif medya toplum kökenlidir, insanları birleştirirken aynı zamanda sivil toplum anlayışını da derinleștirir (Bailey, Cammaerts ve Carpentier , 2008, s. 31-32).

\section{Yöntem}

\section{1. Çalışmanın Amacı ve Literatüre Katkısı}

$\mathrm{Bu}$ bilgiler ışığında, çalışmada sivil toplum kuruluşlarının sosyal medya kullanım pratikleri iki aşamada incelenmiştir. Bu bağlamda çalışmanın ilk aşamasında KKTC'deki resmi kayıtlı kadın sivil toplum kuruluşlarının sosyal medya ortamlarındaki (Facebook, Twitter ve Instagram) görünürlükleri ortaya konmuştur. Çalışmanın ikinci aşamasında ise Kuzey Kıbrıs'taki kadın aktivist hareketlerin ve sivil toplum kuruluşlarının önde gelen aktif bir örneği olan Mesarya Kadınları İnisiyatifi'nin resmi Facebook hesabına yönelik 1 Ocak 2019-31 Mart 2019 tarihleri arasında 3 (üç) aylık içerik analizi uygulanmıştır. Söz konusu tarih aralığı, Mesarya Kadınları Ínisiyatifi'nin Facebook hesabını en aktif kullandığı aylar ve güncel olması sebebiyle seçilmiştir. Bu yolla söz konusu paylaşımları üzerinden sosyal medya kullanım pratiklerinin betimlenmesi amaçlanmaktadır. Kuzey Kıbrıs özelinde sivil toplum kuruluşlarına yönelik yapılan çalışmaların sınırlı sayıda olması (Ciftci, 2018; Kaya \& Sagsan, 2015; Karam \& Saydam, 2015; Işık, 2013) ve kadın sivil toplum kuruluşları ile yapılan çalışmaların eksikliği bu çalışmanın özgünlüğünü ve literatüre katkısını ortaya koymaktadır.

\section{2. Çalışılan Evren ve Örneklem}

$\mathrm{Bu}$ çalışmada iki aşamada inceleme yapıldığı için çalışmanın birinci aşamasının evren ve örneklemi Kuzey Kıbrıs Türk Cumhuriyeti İç İşleri Bakanlığı'na bağlı tüm sivil toplum kuruluşlarını içermektedir. Bu bağlamda, birinci aşamada evren içinden amaçlı örnekleme tekniği kullanılarak kadın sivil toplum kuruluşu olarak seçilen 42 (kırk iki) kadın sivil toplum kuruluşu yine Kuzey Kıbrıs Türk Cumhuriyeti İç İşleri Bakanlığı'nın ayırdığı şekliyle 5 (beş) farklı yerleşim bölgesine ayrılarak incelenmiştir. Çalışmanın ikinci aşaması için ise en fazla takipçi ve sosyal medya ortamlarında en aktif olan sivil inisiyatif sayılabilecek Mesarya Kadınları Ínisiyatifi'nin son dönemde parlaması, aykırı örneklem ve amaçlı örnekleme tekniği bir arada düşünülerek seçilmiştir. Mesarya Kadınları Inisiyatifi amaçlarını ve hedeflerini şu şekilde tanımlamaktadır: Mesarya bölgesinde yaşayan kadınları güçlendirmek, örgütlemek ve bölge insanını toplumsal cinsiyet eşitliğini politikalarıyla tanıştırmak hedefindedir. Sayfaları 7 Şubat 2015 tarihinde kurulmuş 
olup, toplam sayfalarını beğenen sayısı yaklaşık olarak 3.290 (üç bin iki yüz doksan) dolaylarında ve toplam sayfalarını takip eden sayısı ise yine yaklaşık olarak 3.300 (üç bin üç yüz) dolaylarındadır.

\subsection{Veri Toplama Aracı, Süreci ve Araştırma Yöntemi}

Araştırmanın birinci aşamasında nitel araştırma veri toplama araçlarından birisi olan belge analiz yöntemi kullanılmıştır. Bu bağlamda Kuzey Kıbrıs Türk Cumhuriyeti İç İşleri Bakanlığı'nın resmi web sitesinde ${ }^{1}$ açıklamış olduğu kayıtlı sivil toplum kuruluşlarının yerleşim bölgelerine göre ayrılmış listeleri incelenmiş ve 11 (on bir) farklı kategoride listelenen sivil toplum kuruluşlarından (trafik, dayanışma, kadın, spor, çevre, şehit, sağlık, sanat, kültür, emekli ve mesleki) kadın sivil toplum kuruluşları çıkarılmıştır. Bu bağlamda kadın sivil toplum kuruluşlarının Facebook, Instagram ve Twitter ortamlarında resmi hesaplarının olup olmadığı incelenmiștir. Çalışmanın ikinci aşamasında ise Mesarya Kadınları Ínisiyatifi resmi Facebook hesabı üzerinden 1 Ocak 2019- 31 Mart 2019 tarihleri arasındaki paylaşımları indirilmiş ve paylaşımların ekran görüntüleri alınmıştır. Söz konusu paylaşımlar 7 (yedi) farklı kategoride değerlendirilmiştir. Bu kategoriler sırasıyla: Muhalif Siyaset, Kadın Dayanıșması, Kadın Cinayetleri, Kara Mizah, Kültür \& Sanat, Eğitim \& Farkındalık ve Ekonomidir.

Çalışmada içerik analizi için Strauss ve Corbin (1990)'ın üç tür kodlama biçimi çalışmaya göre uyarlanarak kullanılmıştır. Şöyle ki Strauss ve Corbin (2019)'a göre bu üç tür kodlama şu şekilde sıralanmaktadır:

- Daha önce belirlenmiş kavramlara göre yapılan kodlama

- Verilerden çıkarılan kavramlara göre yapılan kodlama

- Genel bir çerçeve içinde yapılan kodlama (Yıldırım \& Şimșek, 2016, s.244-246).

Üçlü kodlama türünden çalışmada genel bir çerçeve içinde yapılan kodlama yöntemi kullanılmıştır. Buna göre paylaşımların analizinden önce kadın örgütü olması sebebiyle var olması ön görülen kategoriler (Kadın Dayanışması, Kadın Cinayetleri ve Farkındalık gibi) ile kavramsal bir altyapı oluşturulmuştur. Daha sonra ortaya çıkan yeni kategoriler kodlamaya eklenmiştir (Ekonomi, Kültür ve Sanat gibi). Bu yolla, önceden belirlenen kategoriler kodlama listesi ile içerik analizi yönlendirilirken, tümevarımcı bir anlayış ile verilen incelenmesi sonucu ortaya çlkan yeni kategoriler kodlama listesine eklenmiştir. Söz konusu kategorilerin çalıșmadaki anlamlarına ilişkin açıklamalar ve örnek paylaşımlar Tablo 1'de verilmiştir. 
Tablo 1: Çalışmada Kullanılan Kategoriler ve Örnek Paylașımlar

\begin{tabular}{|c|c|c|}
\hline Kategori & Çalışmadaki Karşılığı & Örnek Paylaşım \\
\hline $\begin{array}{l}\text { Eğitim \& } \\
\text { Farkındalık }\end{array}$ & $\begin{array}{l}\text { Toplumsal Cinsiyet konulu } \\
\text { eğitim, seminer ve farkındalık } \\
\text { etkinliklerini içeren paylaşımlar }\end{array}$ & 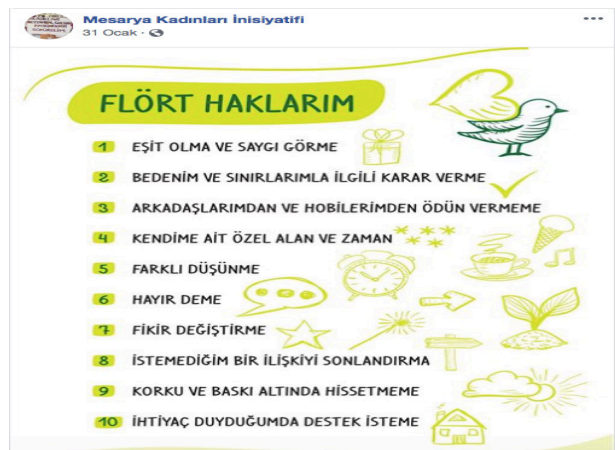 \\
\hline Ekonomi & Ekonomik kriz ve işsizlikle ilgili paylaşımlar & 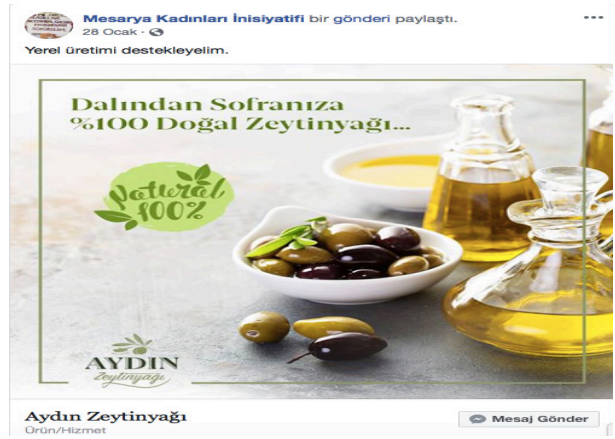 \\
\hline $\begin{array}{l}\text { Kadın } \\
\text { Dayanışması }\end{array}$ & $\begin{array}{l}\text { Kadın örgütlenmeleri, kadın hareketleri ve } \\
\text { protesto ve gösterileri içeren paylaşımlar }\end{array}$ & 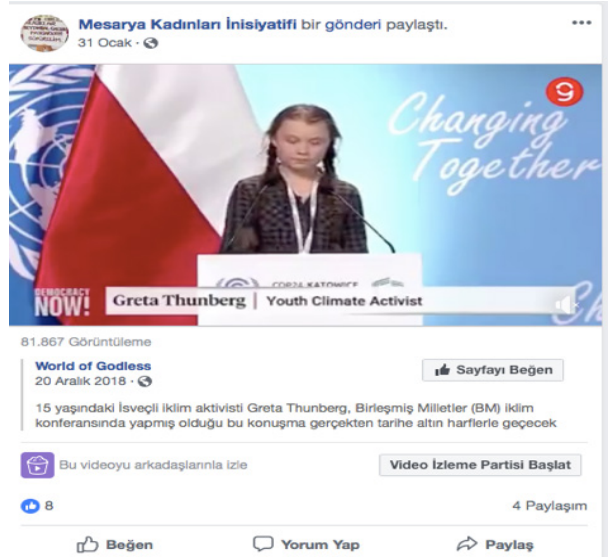 \\
\hline Kadına Şiddet & $\begin{array}{l}\text { Kadına uygulanan şiddetleri } \\
\text { konu alan paylaşımlar }\end{array}$ & 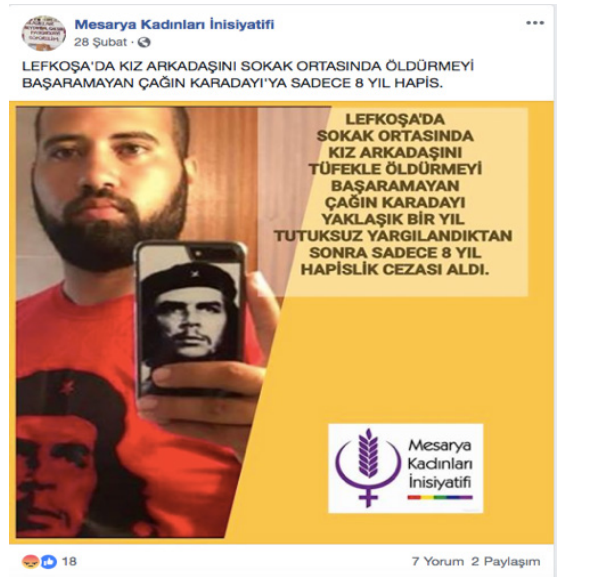 \\
\hline
\end{tabular}




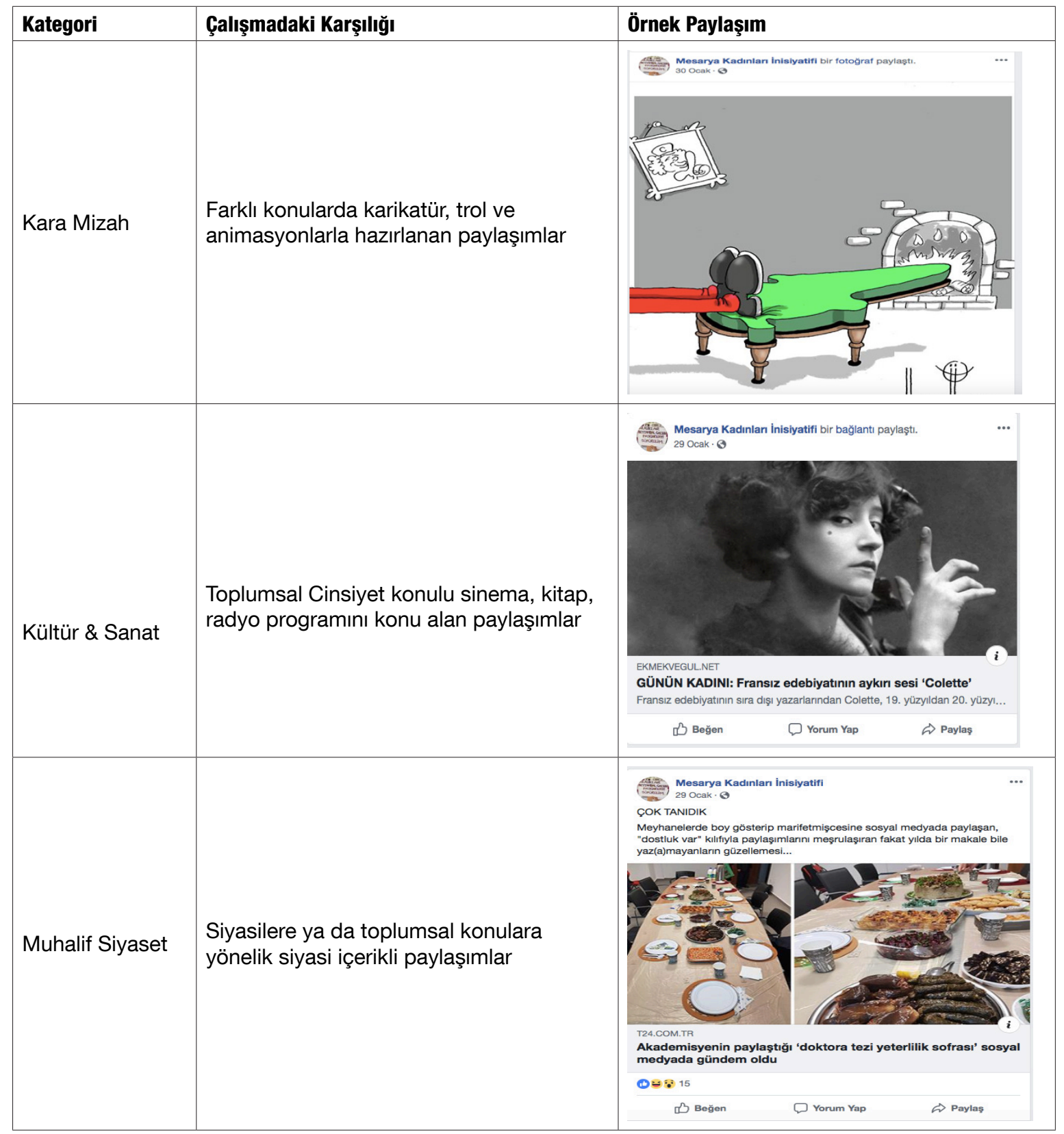

\section{Bulgular}

KKTC sivil toplum kuruluşlarındaki artış Annan Planı dönemine denk gelmekle birlikte kaymakamlıklara bağlı olan sivil toplum kuruluşlarının listeleri İç İşleri Bakanlığı'ndan alınarak aşağıda listelenmiştir. Tablo 2, KKTC'deki yerleşim yerlerine göre toplam sivil toplum kurulușlarını ve kadın sivil toplum kurulușu olarak kategorize edilen sivil toplum kuruluşlarını göstermektedir. Tabloya göre, KKTC'de 5 (beş) yerleşim bölgesinde toplam 1557 (bin beş yüz elli yedi) sivil toplum kuruluşu bulunmaktadır. Bu sivil toplum kuruluşlarının 42 (kırk iki) tanesi (\%3.12) kadın sivil toplum kuruluşu olarak kaydedilmiştir. Ayrıca kadın sivil toplum kuruluşlarının Gazimağusa yerleşim bölgesinde diğer yerleşim bölgelerine nazaran daha fazla olduğu gözlemlenmiştir $(n=16)$. Diğer taraftan Girne bölgesinde en az kadın sivil toplum kuruluşu bulunmaktadır $(n=1)$. Toplam sivil toplum kuruluşlarında ise Lefkoşa bölgesi en fazla sivil toplum kuruluşunun bulunduğu ( $n=944)$ yerleşim bölgesi iken, Güzelyurt-Lefke bölgesinde en az sivil toplum kuruluşu bulunmaktadır $(n=24)$. 
Tablo 2: KKTC STK'ların Yerleșim Yerine Göre Dağılımı ve Kadın STK'ların Oranı

\begin{tabular}{|l|c|c|c|}
\hline Yerleşim Yeri & Toplam STK & Kadın STK & \% \\
\hline İskele & 150 & 7 & 4.6 \\
\hline Gazimağusa & 246 & 16 & 6.5 \\
\hline Girne & 176 & 4 & 2.2 \\
\hline Güzelyurt-Lefke & 63 & 1 & 1.5 \\
\hline Lefkoşa & 944 & 13 & 1.3 \\
\hline Toplam & 1557 & 42 & 2.6 \\
\hline
\end{tabular}

Tablo 3 sosyal medya ortamlarını (Facebook, Instagram, Twitter) kullanan KKTC kadın sivil toplum kuruluşlarının yerleşim bölgelerine göre dağılımını özetlemektedir. Buna ilaveten Tablo 3 sosyal medya ortamlarından Facebook resmi hesabı olan KKTC kadın sivil toplum kuruluşlarının yerleşim bölgesine göre sayısal dağılımını göstermektedir. Tablo 3'de görüldüğü șekliyle $42(n=42)$ kadın sivil toplum kuruluşundan $16(n=16)$ tanesinin Facebook hesabı bulunmaktadır (\%38). Așağıda Tablo 3 ve Tablo 4'de ortaya koyulduğu üzere Facebook KKTC kadın sivil toplum kuruluşlarının en fazla tercih ettiği sosyal medya ortamı olmuştur. Gazimağusa en fazla Facebook ortamında hesabı bulunan KKTC kadın sivil toplum kuruluşuna sahip yerleşim bölgesi olmuştur $(n=8)$.

Tablo 3: Sosyal Medya Ortamlarını Kullanan KKTC Kadın STK'ların Yerleşim Yerine Göre Dağılımı

\begin{tabular}{|l|c|c|c|}
\hline Yerleşim Yeri & Facebook & Instagram & Twitter \\
\hline İskele & 2 & - & - \\
\hline Gazimağusa & 8 & - & - \\
\hline Girne & - & - & - \\
\hline Güzelyurt-Lefke & - & - & - \\
\hline Lefkoşa & 6 & - & - \\
\hline Toplam & 16 & - & - \\
\hline
\end{tabular}

Dijital dönüşümlerle birlikte sivil toplum kuruluşlarının geleneksel medyada yer bulamama sorununa alternatif olacak şekilde sosyal medyaya yönelimlerini ele alan bu çalışma kapsamında, KKTC kadın sivil toplum kuruluşlarının sosyal medya ortamlarında resmi hesaplarının olup olmadığı incelenmiștir. Bu bağlamda, en fazla kadın sivil toplum kuruluşuna sahip olan Gazimağusa bölgesindeki kadın sivil toplum kuruluşlarının diğer yerleşim bölgelerindeki kadın sivil toplum kuruluşlarına nazaran sosyal medya ortamlarında daha fazla görünür olduklarını söylemek doğru olacaktır.

Tablo 4: Facebook Ortamında Resmi Hesabı Bulunan KKTC Kadın STK'ların Yerleşim Yerine Göre Yüzdelik Dağılımı

\begin{tabular}{|l|c|c|c|}
\hline Yerleşim Yeri & Toplam Kadın STK & $\begin{array}{c}\text { Facebook Resmi Hesabı } \\
\text { Bulunan Kadın STK }\end{array}$ & $\%$ \\
\hline İskele & 7 & 2 & 28.5 \\
\hline Gazimağusa & 16 & 8 & 47 \\
\hline Girne & 4 & - & - \\
\hline Güzelyurt-Lefke & 1 & - & - \\
\hline Lefkoşa & 13 & 6 & 46.1 \\
\hline Toplam & 42 & 16 & 38 \\
\hline
\end{tabular}


Tablo 5: Resmi Web Sitesi Olan KKTC Kadın STK'ların Yerleşim Yerine Göre Yüzdelik Dağılımı

\begin{tabular}{|l|c|c|c|}
\hline Yerleşim Yeri & Toplam Kadın STK & $\begin{array}{c}\text { Resmi Web Sitesi } \\
\text { Olan Kadın STK }\end{array}$ & $\%$ \\
\hline İskele & 7 & - & - \\
\hline Gazimağusa & 16 & - & - \\
\hline Girne & 4 & 1 & 25 \\
\hline Güzelyurt-Lefke & 1 & - & - \\
\hline Lefkoşa & 13 & 2 & 15.38 \\
\hline Toplam & 42 & 3 & 7.14 \\
\hline
\end{tabular}

KKTC kadın sivil toplum kuruluşlarının sosyal medya ortamlarındaki görünürlükleri araştırılırken ortaya çıkan bir başka önemli bulgu ise şu şekildedir: Bu bağlamda, söz konusu kadın sivil toplum kuruluşlarının resmi web sitelerinin olmaması da dijital çağda kendilerini topluma ifade etme biçimleri bakımından çarpıcı bir sonuç olmuştur. Tablo 4 ve Tablo 5 resmi web sitesi olan KKTC kadın sivil toplum kuruluşlarının yerleșim yerine göre yüzdelik dağılımını ve isimlerini özetlemektedir. Bu bilgiler ıșığında bakıldığında, en fazla resmi web sitesine sahip KKTC kadın sivil toplum kuruluşunun Lefkoşa merkez yerleșim bölgesinde $(n=2)$ toplandığını söylemek mümkündür.

Tablo 6: Resmi Web Sitesi Olan KKTC Kadın STK'ları

\begin{tabular}{|l|}
\hline Kadın STK'ların isimleri \\
\hline KKTC İş Kadınları Derneği \\
\hline Kadından Yaşama Destek Derneği \\
\hline Girne Inner Wheel \\
\hline
\end{tabular}

Araştırmanın ikinci kısmında Mesarya Kadınları Inisiyatifi'nin resmi Facebook hesabındaki paylaşımlarının 1 Ocak 2019- 31 Mart 2019 tarihleri arasındaki 3 (üç) aylık paylaşımlarının betimsel analizi yapılmıştır. Bu bağlamda çıkan sonuçlara göre Mesarya Kadınları Ínisiyatifi, kaymakamlığa bağlı resmi bir sivil toplum kuruluşu olmamasına rağmen KKTC kadın kuruluşları arasında en aktif ve etkileşime sahip örgütlenme olarak önemini korumaktadır. Tablo 6, Tablo 7 ve Tablo 8 Mesarya Kadınları Ínisiyatifi'nin aylara göre paylaşım sayılarını ve yüzdeliklerini listelemektedir. İnisiyatifin paylaşımları 7 (yedi) kategoride incelenmiştir. Bu kategoriler Eğitim \& Farkındalık, Ekonomi, Kadın Dayanışması, Kadına Şiddet, Kara Mizah, Kültür \& Sanat ve Muhalif Siyasettir. Söz konusu tablolar aynı zamanda paylaşımların aylar bazında kategorilere göre dağılımının betimsel analizini ortaya koymaktadır.

Tablo 7: Kategorilere Göre Ocak Ayı Paylaşımlarının Betimsel Analizi

\begin{tabular}{|l|c|c|c|c|}
\hline Kategori & $\begin{array}{c}\text { Toplam Paylaşım } \\
\text { Sayısı }\end{array}$ & $\begin{array}{c}\text { Toplam Beğeni } \\
\text { Sayısı }\end{array}$ & $\begin{array}{c}\text { Toplam Yorum } \\
\text { Sayısı }\end{array}$ & $\begin{array}{c}\text { Toplam Paylaşma } \\
\text { Sayısı }\end{array}$ \\
\hline Eğitim \& Farkındalık & 27 & 358 & 20 & 31 \\
\hline Ekonomi & 12 & 84 & 4 & 14 \\
\hline Kadın Dayanışması & 29 & 360 & 26 & 40 \\
\hline Kadına Şiddet & 3 & 36 & - & 9 \\
\hline Kara Mizah & 35 & 562 & 32 & 32 \\
\hline Kültür \& Sanat & 28 & 570 & 6 & 110 \\
\hline Muhalif Siyaset & 78 & 921 & 130 & 287 \\
\hline Toplam & 212 & 2.891 & 218 & 51 \\
\hline
\end{tabular}


Tablo 7'de gösterildiği şekliyle Mesarya Kadınları İnisiyatifi'nin Ocak ayı paylaşımlarında $(n=212)$ en fazla paylaşımda bulunduğu kategori muhalif siyaset kategorisidir $(n=78)$. Buna karşın, Ocak ayı içerisinde en az paylaşımda bulunulan kategori kadına şiddet olmuştur $(n=3)$. Ayrıca, toplam beğeni sayısı, toplam yorum sayısı ve takipçilerin paylaşımları kendi sayfalarında paylaşma sayılarına bakıldığında ise Tablo 7'ye göre Mesarya Kadınları Ínisiyatifi'nin Ocak ayı paylaşımlarında en fazla beğeniyi alan paylaşımları yine muhalif siyaset kategorisinden olmuştur $(n=921)$. Buna ilaveten Tablo 6'da en fazla yorum alan paylaşımlar $(n=130)$ ile takipçilerin paylaşımları kendi sayfalarında paylaşma sayıları $(n=110)$ incelendiği aynı kategorideki (muhalif siyaset) paylaşımlarda rakamların yüksek olduğunu göstermektedir.

Tablo 8: Kategorilere Göre Şubat Ayı Paylaşımlarının Betimsel Analizi

\begin{tabular}{|l|c|c|c|c|}
\hline Kategori & $\begin{array}{c}\text { Toplam Paylaşım } \\
\text { Sayısı }\end{array}$ & $\begin{array}{c}\text { Toplam Beğeni } \\
\text { Sayısı }\end{array}$ & $\begin{array}{c}\text { Toplam Yorum } \\
\text { Sayısı }\end{array}$ & $\begin{array}{c}\text { Toplam } \\
\text { Paylaşma Sayısı }\end{array}$ \\
\hline Eğitim \& Farkındalık & 29 & 209 & 24 & 50 \\
\hline Ekonomi & 15 & 241 & 25 & 20 \\
\hline Kadın Dayanışması & 21 & 248 & 2 & 16 \\
\hline Kadına Şiddet & 10 & 162 & 14 & 29 \\
\hline Kara Mizah & 34 & 599 & 23 & 47 \\
\hline Kültür \& Sanat & 27 & 206 & 9 & 49 \\
\hline Muhalif Siyaset & 41 & 640 & 61 & 94 \\
\hline Toplam & 177 & 2.305 & 158 & 305 \\
\hline
\end{tabular}

Tablo 8'de gösterildiği şekliyle Mesarya Kadınları Ínisiyatifi'nin Şubat ayı paylaşımlarında $(n=177)$ en fazla paylaşımda bulunduğu kategori muhalif siyaset kategorisidir $(n=41)$. Diğer taraftan, Şubat ayı içerisinde en az paylaşımda bulunulan kategori kadına şiddet olmuştur $(n=10)$. Ayrıca, toplam beğeni sayısı, toplam yorum sayısı ve takipçilerin paylaşımları kendi sayfalarında paylaşma sayılarına bakıldığında ise Tablo 8'e göre Mesarya Kadınları Ínisiyatifi'nin Şubat ayı paylaşımlarında en fazla beğeniyi alan paylaşımları yine muhalif siyaset kategorisinden olmuştur $(n=640)$. Fakat benzer şekilde Şubat ayı içerisindeki kara mizah kategorisindeki paylaşımlarda yüksek oranda beğeni almıştır ( $n=599)$. Tablo 9'da en fazla yorum alan paylaşımlar $(n=61)$ ile takipçilerin paylaşımları kendi sayfalarında paylaşma sayıları $(n=94)$ incelendiğinde muhalif siyaset kategorisindeki paylaşımlarda rakamların yüksek olduğunu göstermektedir.

Tablo 9: Kategorilere Göre Mart Ayı Paylașımlarının Betimsel Analizi

\begin{tabular}{|l|c|c|c|c|}
\hline Kategori & $\begin{array}{c}\text { Toplam Paylaşım } \\
\text { Sayısı }\end{array}$ & $\begin{array}{c}\text { Toplam Beğeni } \\
\text { Sayısı }\end{array}$ & $\begin{array}{c}\text { Toplam Yorum } \\
\text { Sayısı }\end{array}$ & $\begin{array}{c}\text { Toplam } \\
\text { Paylaşma Sayısı }\end{array}$ \\
\hline Eğitim \& Farkındalık & 47 & 701 & 31 & 147 \\
\hline Ekonomi & 16 & 274 & 24 & 47 \\
\hline Kadın Dayanışması & 33 & 1.026 & 33 & 176 \\
\hline Kadına Şiddet & 25 & 861 & 85 & 119 \\
\hline Kara Mizah & 23 & 622 & 13 & 51 \\
\hline Kültür \& Sanat & 22 & 392 & 7 & 40 \\
\hline Muhalif Siyaset & 75 & 1.957 & 141 & 144 \\
\hline Toplam & 241 & 5.833 & 334 & 724 \\
\hline
\end{tabular}

Tablo 9'da gösterildiği şekliyle Mesarya Kadınları İnisiyatifi'nin Mart ayı paylaşımlarında $(n=241)$ en fazla paylaşımda bulunduğu kategori muhalif siyaset kategorisidir $(n=75)$. Diğer taraftan, Mart ayı içerisinde en az paylaşımda bulunulan kategori ekonomi olmuştur $(n=16)$. Ayrıca, toplam beğeni sayısı, toplam yorum sayısı ve takipçilerin 
paylaşımları kendi sayfalarında paylaşma sayılarına bakıldığında ise Tablo 8'de verildiği şekliyle Mesarya Kadınları İnisiyatifi'nin Mart ayı paylaşımlarında en fazla beğeniyi alan paylaşımları yine muhalif siyaset kategorisinden olmuştur $(n=1.957)$. Bununla birlikte Mart ayı içerisindeki kadın dayanışması kategorisindeki paylaşımlarda yüksek oranda beğeni almıştır $(n=1.026)$. Tablo 9'a göre en fazla yorum alan paylaşımlar $(n=141)$ ile muhalif siyaset kategorisindeki paylaşımlardayken takipçilerin paylaşımları kendi sayfalarında paylaşma sayıları $(n=176)$ incelendiği kadın dayanışması kategorisindeki paylaşımlarda rakamların yüksek olduğu gösterilmiştir. Kategoriler ve aylar bazında incelendiğinde, Mart ayı boyunca Mesarya Kadınları Inisiyatifi'nin en fazla paylaşımda bulunduğu ve takipçileri ile en fazla Mart ayı boyunca yaptığı paylaşımlar aracılığı ile etkileşime geçtiği ortaya çıkmıştır. Tablo 10 kategorilerin aylar bazında karşılaştırmasını özetlemektedir.

Tablo 10: Kategorilerin Aylar Bazında Karşıllaştırılması

\begin{tabular}{|l|c|c|c|c|}
\hline Aylar & $\begin{array}{c}\text { Toplam Paylaşım } \\
\text { SayıSı }\end{array}$ & $\begin{array}{c}\text { Toplam Beğeni } \\
\text { SayıSı }\end{array}$ & $\begin{array}{c}\text { Toplam Yorum } \\
\text { Sayısı }\end{array}$ & $\begin{array}{c}\text { Toplam Paylaşma } \\
\text { Sayısı }\end{array}$ \\
\hline Ocak & 212 & 2.891 & 218 & 287 \\
\hline Şubat & 177 & 2.305 & 158 & 305 \\
\hline Mart & 241 & 5.833 & 334 & 724 \\
\hline Toplam & 630 & 11.029 & 710 & 1.316 \\
\hline
\end{tabular}

\section{Tartışma ve Sonuç}

2012 yılından itibaren Kıbrıs'ın kuzeyinde yükselen hareketlerinin başında şüphesiz ki Kadın Hareketi ve bu alandaki faaliyetler gelmektedir. Kadınların kendi yaşamlarına, toplum içerisindeki sosyal ve ekonomik konumlarına dair sorgulamalarındaki farkındalık arttıkça, şehirlerde ve kırsal bölgelerdeki kadın örgütlerinin sadece sayılarının artışı değil görünürlüklerinde de artış söz konusu olmuştur. Bağımsız kadın örgütlenmelerindeki bu yükseliş, karma örgütlenmelerdeki dayanışma ağlarını geliştirirken, toplumsal alana müdahale imkânlarını da artırmıștır. Bu noktada sosyal medyanın pratik olarak kullanılmaya başlanmasına paralel olarak sadece farkındalık yaratmaya çalışan değil, politik süreçlere bilfiil müdahil olarak hayatı dönüştürmeye çalışan kadın örgütlenmeleri köylerde ve kasabalarda da varlığını hissettirmiştir. Bu örgütlenmelerden önemli bir tanesi de Mesarya Kadınlar Inisiyatifi olmuştur.

Dijital dönüşümlerle birlikte sivil toplum kuruluşlarının geleneksel medyadan sosyal medya ortamlarına kaymasını ele alan bu çalışmada, KKTC kadın sivil toplum kuruluşlarının sosyal medya ortamlarında resmi hesaplarının olup olmadığı incelenmiş ve kullanım pratikleri ortaya konmuştur. Bu bağlamda, en fazla kadın sivil toplum kuruluşuna sahip olan Gazimağusa bölgesindeki kadın sivil toplum kuruluşlarının diğer yerleşim bölgelerindeki kadın sivil toplum kuruluşlarına nazaran sosyal medya ortamlarında daha fazla görünür oldukları ortaya çıkmıştır. Bununla birlikte Kuzey Kıbrıs özelinde, kadın STK Gazimağusa bölgesinde daha yoğunluk göstermektedir. Facebook, KKTC kadın STK'ların en fazla tercih ettiği sosyal medya ortamıdır. Bir başka deyișle literatürde rizom olarak alternatif medya şeklinde ortaya koyulan yaklaşımla birlikte Mesarya Kadınları Inisiyatifi'nin toplum kökenli bir hareketten yola çıkarak insanları birleştiren ama aynı zamanda sivil toplum anlayışını alternatif medyayı kullanarak derinleştiren rolü önemlidir.

Çalışmanın ikinci aşamasında ele alından Kuzey Kıbrıs'ta Mesarya Kadınları Inisiyatifi, Mart ayı boyunca yaptığı paylaşımlarda daha fazla beğeni, yorum ve geri paylaşım almıştır. 
Mesarya Kadınları Ínisiyatifi'nin paylaşımlarında öne çıkan kategori muhalif siyasi paylaşımlar ve kara mizah içerikli paylaşımlar olmuştur. Kategoriler bazında bakıldığında Mesarya Kadınları Ínisiyatifi'nin 7 (yedi) farklı kategorisindeki paylaşımlarının büyük çoğunluğunun yönetenlere yönelik muhalif görüşlerden oluştuğunu söylemek yerinde olacaktır. Yukarıda belirtildiği şekliyle paylaşımların Mart ayında yoğunlaşması ve muhalif siyasi paylaşımların yoğunlukta olması paylaşımların içeriğinin Türkiye Cumhuriyeti 31 Mart 2019 Yerel Seçimleri ile ilgili olmasından ötürü paralellik göstermekte ve anlamlı bulgular ortay koymaktadır. Paylaşımların odağını sadece Kuzey Kıbrıs, Türkiye ve Avrupa oluşturmamış, dünyanın çeşitli yerlerinde yaşanan kadın içerikli konuları da takipçilerinin bilgisine sunmuştur. Bu noktada, söz konusu aylardaki paylaşımlarda Kuzey Kıbrıs odağı dışındaki paylaşımlar Türkiye Cumhuriyeti 31 Mart 2019 Yerel Seçimlerinin yanı sıra, Orta Doğu ülkelerinde toplumsal cinsiyet konusuna yönelik yapılan yanlış tutumlarla birlikte, yeni anlayışların somut örneklerinden oluşmaktadır. Kara mizah kategorisindeki paylaşımlarında Mesarya Kadınları İnisiyatifi çoğunlukla takipçilerinin arasında bulunan grafik tasarımcıların hazırlamış olduğu karikatür ve trolleri kullanarak çeşitli odaklarda eleştirel yaklaşımını ortaya koymaktadır oluşmaktadır. Bunlara en güzel örnek olarak Birleşik Krallık kraliçesi Elizabeth'in karikatürü ile Brexit eleştirisi verilebilir. Burada daha önce belirtilen Orta Doğu ülkelerine yönelik toplumsal cinsiyet paylaşımlarından ziyade kara mizah kategorisindeki odak ülkeler çoğunlukla KKTC, Birleşik Krallık ve Türkiye olmuştur. Karikatürlerin içeriklerine bakıldığında yine Türkiye Cumhuriyeti 31 Mart 2019 Yerel Seçimlerinde Türkiye Komünist Partisi Tunceli adayı Fatih Mehmet Maçoğlu'na yönelik karikatür ve trolllerin çoğunlukta olduğunu görülmektedir. Bütün bu bulgular, gerek Mesarya Kadınları Ínisiyatifi 'nin muhalif duruşu gerekse sosyal ağları alternatif platformlar olarak kullanması durumuyla örtüşen sonuçlar ortaya koymaktadır. Kadın Cinayetleri ve Kadın Dayanışması kategorisindeki paylaşımlar ise çoğunlukla, dava sürecinde olan örneklerin takibinde olduklarını belirtmek amacıyla paylaşılmış ve paylaşımlarda detaya inilmemiştir. Bu kategorideki paylaşımlarda tıpkı diğer kategorilerdekiler gibi davalar ve kadın cinayetleri üzerine yapılan paylaşımlar Türkiye ve KKTC odaklı olmuştur. Bunun yanı sıra, Mesarya Kadınları Ínisiyatifi Kültür ve Sanat kategorisindeki paylaşımlarında çoğunlukla toplumsal cinsiyet içerikli kitap, dergi, sergi, konser, tiyatro oyunu vb. gibi etkinliklerin duyurusunu ve çıktılarını öne çıkarmıştır. Bu kategorideki paylaşımlarda toplumsal cinsiyet konusunun yanında LGBTI konusuna da dikkat çekilmiş, bu alanda yapılan farkındalık etkinliklerinin paylaşımlarına yer verilmiştir. Literatürde alternatif medyayı ortaya koyarken öne çıkan bir diğer konu ise medya hegemonyası karşısında güç gösterecek politikalara, önceliklere ve perspektiflere alternatif bakış açısı sunmak olmuştur. Bu bağlamda Mesarya Kadınları Inisiyatifi gerek muhalif siyaset kategorisindeki alternatif bakış açılarıyla siyasi ve politik konulara yaklaşımı gerekse yaratıcılık gerektiren kara mizah kategorisindeki eleştirel yaklaşımı ile ses getirmiştir.

Bütün bu bilgiler ışığında, Mesarya Kadınları Ínisiyatifi'nin genel olarak tüm paylaşımlarında muhalif bir bakış açıcıyla takipçilerine farklı konu içeriklerindeki toplumsal cinsiyet farkındalığını yayma amacıyla sistematik olarak paylaşımlarda bulunduğunu söylemek yerinde olacaktır. Takipçi sayılarının günden güne artması durumundan yola çıkarak, çalışmanın birinci aşamasındaki bulgular ışığında Kuzey Kıbrıs'ta Facebook üzerinden yapılacak olan her türlü faaliyetin daha geniş kitlelere ulaşacağı gerçeği üzerinden Mesarya Kadınları Inisiyatifi'nin başarılı bir örgütlenme olduğunu söylemek mümkündür. Bunun yanında paylaşımlarındaki muhalif duruşun zaman zaman temel odak olan toplumsal cinsiyet konularında Mesarya bölgesi kadınlarını 
bilinçlendirmekten saparak, mevcut siyasi mekanizmaları eleștirmenin öne çıktığının da altını çizmek yerinde olacaktır. Bütün bu bilgiler ışı̆̆ında alternatif medyanın sivil toplumu bağlayan gücü ve ifade etme firsatı sunması açısından Mesarya Kadınları Ínisiyatifi literatürdeki kavramsallaștırmaların başarılı bir örneğini sunmaktadır.

Bütün bu bilgiler ışığında önceleri şarkı söylemek amacıyla bir arada toplanan kadınlardan oluşan inisiyatif Akdoğan ve civarı köylerde yaşayan insanların sosyalleşebileceği bir ortam yaratmaktaydı. Bir şeyleri değiştirme isteği ve bunun için gerekli dönüştürücü enerjiye, güce, inanca sahip olan bu kadınlarla hayal etmeye; sorunları, soruları ve talepleri konuşmaya başlayan inisiyatif teoride netleștirdikleri ile pratikte yaşadıkları arasında köprüler kurmayı amaçlayarak faaliyetlerine başlamıştır. İnisiyatif'in kurucu başkanı Hare Yakula'nın ifade ettiği şekliyle 'Bizler; kadın gözüyle hayatı yeniden kurgulamaya çalışan, anti-hiyerarşik, eşitlikçi, insanları ırk, dil, din, cinsiyet, etnik köken, engellilik ve cinsel yönelimlerinden dolayı ayrıştırmayan, çevre ve hayvan dostu, tabandan gelen ve yatay örgütlenen bir kadın inisiyatifiyiz'2.

Pek çok anlamlı proje ve etkinliğe imza atan inisiyatif, kadın hakları ağırlıkta olmak üzerde insan hakları ekseninde on beş günde bir halka açık söyleşiler organize etmiş ve Kadının İnsan Hakları Eğitimi çalışmalarını Feminist Atölye desteğiyle yürütmüştür. Bunun yanında Mülteci Hakları Derneği ile mülteci sorununu, Kuir Kıbrıs Derneği ile LGBTi bireyleri ve homofobiyi, Sosyal Riskleri Önleme Vakfı'yla kadın sığınma evini ve alo şiddet hattını ortaya koymuştur. Alan bilgisine sahip birçok aktivistle vicdani reddi, Aile Yasası'nı, barış ve olası bir çözümde kadınların yerini, toplumsal cinsiyet eşitsizliğini ve eğitimdeki önemini ortaya koyan sohbetler düzenlemiş ve bunlara ek olarak kadın filmleri izleyip, tartışma ortamı oluşturmuştur. Bütün bu etkinliklerin en çarpıcı olanı Patronsuz Kadın Emeği Standı olarak gösterilebilir. Literatürde ortaya koyulan alternatif medyanın kavramsallaştırmasında öne çıkan 4 temel unsurun çalışmanın bulguları ile örtüştüğünü söylemek yerinde olacaktır. Şöyle ki, Mesarya Kadınları Inisiyatifi sadece kadın örgütü olmakla kalmamış diğer topluluklara LGBTI vb. aktif katkı koyarak resmi Facebook hesabında söz konusu aylar içerisinde yer vermiştir. Bir başka deyişle bastırılmış ve ana akım medya tarafından görünür olmayan konuların konuşulur olmasını sağlamış bir bakıma açığa çıkarmıştır.

Paylaşımları ve duruşlarıyla politika yaptıkları yönünde eleştirilere maruz kalan inisiyatif, paylaşımları ve söylemleriyle eril zihniyete karşı durmaktadır. Şarkı söylemek üzere bir araya gelen koro ile başladıkları bu serüvende zaman içerisinde hayatı değiştirmek ve yaşamı dönüştürmek adına başarılı projelere imza atmıştır. Bütün bu başarılarına ilaveten sadece seçim zamanlarında oy toplamak üzere kişisel sosyal medya hesaplarından paylaşımlarda bulunan kadınlara nazaran inisiyatif, gerek sosyal medya kullanım pratikleri gerekse muhalif duruşu ile Kuzey Kıbrıs toplumunda ses getirmiş başarılı bir girişim olarak kabul edilmelidir. Paylaşımlarının çok yönlü oluşu sebebiyle kadınları toplumda yaşanan sorunlardan etkilenmeyen pasif rolden çıkarıp tartışmaların ve eleştirel bakışın aktif parçası konumuna gelmesinde oynadığı rol sebebiyle de önemlidir.

İlerleyen çalışmalarda, kadın STK'ları ile diğer STK'ların dijital dönüşümlerde gösterdikleri farklılıklar karşılaştırmalı olarak incelenebilir. Bu bağlamda çalışmanın ön aşamasında elde edilen bilgiler ışığında Kuzey Kıbrıs özelinde kültür ağırlıklı STK'ların üstün çoğunluğu gerçeğinden yola çıkarak yapılacak olan karşılaştırmalı ve öznel örneklemler üzerinden kültür STK'larının dijital dönüşümlerini ele alan çalışmalar 
literatüre katkı koyacak nitelikte olacaktır. Bununla birlikte kadın STK'ların belli yerleşim bölgelerinde kümelenmesinin yanında dijital dönüşümleri o denli hızlı olmamıştır, bu durumun nedenleri sosyo-ekonomik açıdan ilerleyen çalışmalarda ele alındığında anlamlı bulgular ortaya çıkacaktır. Bunlara ilaveten, Mesarya Kadınları İnisiyatifi yöneticileri ile derinlemesine mülakatlar yapılarak, ilgili STK'ların sosyal medyaya içerik üretimlerindeki süreçlerinin irdelenebileceği çalışmalar yapılabilir. Bununla birlikte STK (lar) sosyal medyaya içerik üretirken nelere dikkat etmeleri gerektiği ile ilgili etik tartışmalar da literatüre katkı koyacak niteliktedir.

\section{Notlar}

1 KKTC İ ̧̇ Işleri Bakanlığı resmi web sitesi http://icisleri.gov.ct.tr.

2 Hare Yakula ile söyleşi : http://www.yeniduzen.com/mesarya-kadinlar-inisiyatifi-sonuc-olarak-erkeklige-gecmis-ola83134h.htm.

\section{Kaynakça}

Al, H., (2002). Bilgi Toplumu ve Kamu Yönetiminde Paradigma Değişimi, Bilimadamı Yayınları.

Altunay, A. (2012). Geleneksel Medyadan Yeni Medyaya: Görüntü Yüzeyi, Selçuk Üniversitesi Sosyal Bilimler Enstitüsü Dergisi, 27(33), 33-44.

Bailey, O. G., Cammaert, B., \& Carpentier, N. (2008). Understanding Alternative Media, UK: McGraw-Hill Education.

Best, S., \& Kellner, D. (1998). La Política Posmoderna Y La Batalla Por El Futuro, Revista de Ciencias Sociales, 5, 1-29.

Castells, M., \& Himanen, P. (2001). The Finnish model of the information society. Sitra.

Chow, R. (2012). Entanglements, or Trans-medial Thinking about Capture, UK: Duke University Press.

Ciftci, D. (2019). The Application of Solutions Journalism: Strategic Communications and Public Affairs Group in Somalia. Online Journal of Communication and Media Technologies, 9(3), e201914. Erişim: https://www.ojcmt.net/download/theapplication-of-solutions-journalism-strategic-communications-and-public-affairsgroup-in-somalia-5782.pdf

Çiftçi, D. (2018). Communication, Persuasion and Cognition: The Review on Application of the ELM-Model in Political Communication of North Cyprus. Akdeniz Üniversitesi İletişim Fakültesi Dergisi, (29. Özel Sayısı), 133-142.

Ciftci, O., Erdem, R., \& Ciftci, D. (2017). Information Technologies and Changing Organizational Styles: Virtual Communities. Turkish Online Journal of Design Art and Communication, 7(2), 328-336.Erişim: http://tojdac.org/tojdac/VOLUME7ISSUE2_files/tojdac_v07i2115.pdf

Dilmen, N. E. (2007). Yeni Medya Kavramı Çerçevesinde İnternet Günlükleri- Bloglar ve Gazeteciliğe Yansımaları, Marmara İletişim Dergisi, 12.

Friedman, L. (2009). U.S. Patent No. 7,519,911. Washington, DC: U.S. Patent and Trademark Office.

Furuncu, D. (2014). Yeni Toplumsal Hareketler, Küreselleşme ve Dijital Aktivizm: Gezi Parkı Örneği, Yayınlanmamış Yüksek Lisans Tezi, Maltepe Üniversitesi, İstanbul. 
Geray, H. (2003). İletişim ve Teknoloji Uluslararası Birikim Düzeninde Yeni Medya Politikaları, Ankara: Ütopya.

Işık, F. (2013). Comparison of the use of social network in education between North and South Cyprus. Procedia-Social and Behavioral Sciences, 103, 210-219.

Jones, S. (1998). Cybersociety 2.0: Revisiting Computer-Mediated Community and Technology, London: Sage.

Karam, A. A., \& Saydam, S. (2015). An analysis study of improving brand awareness and its impact on consumer behavior via media in North Cyprus (A case study of fast food restaurants). International Journal of Business and Social Science, 6(1).

Karapınar, K. (2006). 'Türkiye'de Sayısal Platform Yayıncılığı Ve Digitürk Beklentiler Ve Sorunlar', Yeni İletişim Ortamları ve Etkileşim Uluslararası Konferansı Kitabı, Marmara Üniversitesi İletişim Fakültesi, İstanbul.

Kaya, T., \& Sagsan, M. (2015, October). The Impact of Tacit Knowledge Capacity on Social Media: An Empirical Research on Physicians In North Cyprus. In 12th International Conference on Intellectual Capital, Knowledge Management And Organizational Learning (pp. 133-141).

Kesim, M., (2008). 'Uzaktan Eğitim Teknolojilerindeki Yönelimler IPV4', Uluslararası Uzaktan Eğitim Konferansı, Ekim.

Komodromos, M. (2014). A Study of Practıtıoners' use of Social Media Tools In Cyprus. Journal of Developmental Entrepreneurship, 19(02), 1450011.

Köse, H. (2007). Küresel'akıntıya karşı'sivil arayışlar alternatif medya. Yirmidört Yayınları.

Lovink, G. (2011). Zero Comments Kernels of Critical Internet Culture, Alternative Politics, $3(3), 256-419$.

Manovich, L. (2001). Post-Media Aesthetics, Transmedia Frictions, The Digital, the Arts, and the Humanities.

McLuhan, M. (1962). Global Köy, (Çev. Düzgören, B., Ö.), İstanbul: Skala.

Morozov E (2007) The new frontier in human rights. Transitions Online, 27 April. Available at: http://www.tol.org/client/article/18700-the-new-frontier-in-human-rights. html

Morozov, E. (2017). Facebook Ve Twitter Sadece Devrimcilerin Gittiği Yerlerdir. F. Aydoğan (Der.). Yeni medya kuramcılarından yeni medya kuramları içinde (s. 23-27), (Çev. Y. Göksun) İstanbul: Der Yayınları.

Offe, C. (1999), "Yeni Sosyal Hareketler: Kurumsal Politikanın Sınırlarının Zorlanması", Yeni Sosyal Hareketler, (Ed.Çayır, K.), İstanbul: Kaknüs Yayınları.

Poster, M. (2018). The second media age. John Wiley \& Sons.

Rodriguez, C. (2000). 'Redeveloping Communication For Social Change. Theory, Practice, Power,' (pp.147-160), In Civil Society and Citizens' Media, (Ed. Karin G. Wilkins), Rowman \& Littlefield.

Rogers, R. (2005). New Media Effects: Do Formats Organize Networks?, Complexity, 10(5), 22-34. 
Soydan, H. (2012). Understanding social work in the history of ideas. Research on Social Work Practice, 22(5), 468-480.

Strauss, A. L. \& Corbin, J. (1990). Basics of Qualitative Research: Grounded Theory Procedures and Techniques. Newbury Park, CA: Sage.

Themistocleous, K. (2017). Model Reconstruction for 3d Vizualization of Cultural Heritage Sites Using Open Data From Social Media: The Case Study of Soli, Cyprus. Journal of Archaeological Science: Reports, 14, 774-781.

Timisi, N. (2003). Yeni İletişim Teknolojileri ve Demokrasi, Ankara: Dost Kitabevi.

Tutar, H.(2000). Kriz ve Stres Ortamında Yönetim. İstanbul: Hayat Yayıncılık.

Underwood, M. (2002). Kamusal Alan Olarak İnternet, Cogito Dergisi, 30.

Şimşek, H., \& Yıldırım, A. (2016). Sosyal bilimlerde nitel araştırma yöntemleri. Ankara: Seçkin Yayıncılık.

Waltz, M.(2005). Alternative and Activist Media. Edinburg: Edinburgh University. 


\title{
Nongovermental Organizations and Digital Transformations: An Investigation on Northern Cypriot Women's Civil Society Organizations
}

\author{
Dilan Çiftçi (Asst. Prof. Dr.)
}

\section{Extended Abstract}

While the debates on technological development and modernity have been able to continue for a long time, addressing information and communication technologies, the rapid development and expansion of the global culture based on technological and modernity is emerging. As it is known, with the invention of railways, steam ships, automobiles and airplanes, landscaping and communication technologies continue to decrease with microchips, satellite antennas, fiber-optic technology and internet. With the widespread use of the Internet, the easy-to-use one should be easy to use. All of this directly affects the practices of everyday life. In addition, individuals with new communication technologies were actively caught in the stage of passing from the passive to the active. It has enabled mass media to expand the boundaries of messages that are open on an internet-based basis. Debates on technological updating and modernity can maintain their importance, such as defending and debating globalization, and supporting protection and the Internet. From the optimistic point of view, while new media technologies have become a cyber public sphere, some people have increased the outlook of the civil will relatively, and a more democratic process has been brought up. On the other hand, new communication environments can provide environments in which opposition groups may be heard.

The fact that people gather around a new publicity and reach out to millions by including dissenting voices in social sharing networks such as, Facebook, Twitter, Instagram etc. is an example of transformed social movements and activism. In this study, the new media environment and women's civil society organizations in the Turkish Republic of Northern Cyprus will be examined in terms of their existence in this new media environment and a descriptive analysis of the social media sharing of Mesarya Women Initiative as an alternative social activist movement will be made. While the women's non-governmental organizations included in the study consist of women's organizations officially registered by the TRNC Ministry of Interior, the Mesarya Women's Initiative, which is considered as an activist movement, stands out with their performance in developing their response to women's problems by utilizing new media. In this study, it will be questioned whether the non-governmental organizations that increase the capacity of stakeholder communication via new media and the network reach the public through the networks and in this context, the focus will be on the framework of digital transformation of TRNC women's NGOs.

Since 2012, Cyprus has got the rising women's movement and the activities. As awareness of women's questioning about their own lives, social and economic positions in society increased, not only the number of women's organizations in cities and rural areas increased, but also their visibility increased. This rise in independent women's organizations has improved the networks of solidarity in mixed organizations and increased the possibility of intervention in the social sphere. At this point, in parallel with the introduction of social media in practice, women organizations not only trying 
to raise awareness but also actively transforming life in political processes have made their presence felt in villages and towns. An important one of these organizations was the Mesarya Women Initiative.

In this study, the transformation of non-governmental organizations from traditional media to social media environments with the help of digital transformations has been examined. In this context, it is revealed that women non-governmental organizations in Famagusta region, which has the highest number of women non-governmental organizations, are more visible in social media environments than women nongovernmental organizations in other settlements. Facebook is the social media environment most preferred by women's NGOs in the TRNC. In other words, with the approach presented in the literature as alternative media as a rhizome, the role of the Mesarya Women Initiative is to unite people from a community-based movement but at the same time deepen the understanding of civil society using alternative media.

In the second phase of the study, the Mesarya Women Initiative in Northern Cyprus received more admiration, comments and feedback on the shares during March. In terms of categories, it would be appropriate to say that the majority of the Mesarya Women's Initiative's 7 (seven) categories of shares are opposed to the rulers. The category featured in the Mesarya Women Initiative's shares was oppositional political and black humor. The shares as specified above condensation in March and opponents of the Republic of Turkey of the contents of the shares that the intensity of the political shares March 31, 2019 in parallel because it is related to Local Elections and meaningful findings has been shown. In the black humor category, the Mesarya Women's Initiative reveals its critical approach in various focus using cartoons and trolls prepared by graphic designers, mostly among its followers. The best examples of this are the cartoons of Queen Elizabeth of England and Brexit criticism.

All these findings are consistent with the opposition of the Mesarya Women Initiative and the use of social networks as alternative platforms. The shares in the women murders and women's solidarity category were mostly shared in order to indicate that they were following the cases in the process of proceedings and were not elaborated in the shares. The shares held in this category at just over murder cases, and women like those in other categories has been focused on Turkey and the TRNC. In addition, the Mesarya Women's Initiative shares its works in the category of culture and art, which are mostly gender-based books, magazines, exhibitions, concerts, theater and so on. events and announcements. In this category, the LGBTI issue was highlighted in addition to gender issues and the awareness activities in this area were shared. Another issue that emerged in the literature while presenting alternative media was to provide an alternative perspective to the policies, priorities and perspectives that would be challenging against the media hegemony. In this context, the Mesarya Women's Initiative has come to the fore with its approach to political issues from the alternative perspectives in the opposition political category and its critical approach to the black humor category that requires creativity.

Keywords: NGOs; Digital Transformations; Social Media; Women's Organizations; Initiative of Mesarya Women; North Cyprus. 
